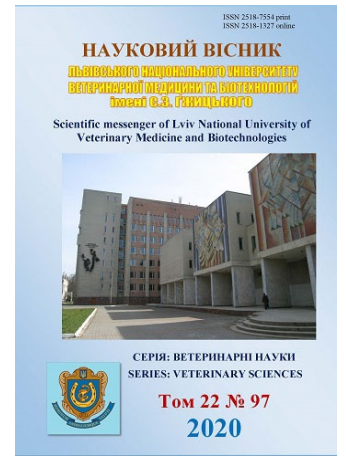

\author{
Науковий вісник Дьвівського національного університету \\ ветеринарної медицини та біотехнологій імені С.3. Гжицького. \\ Серія: Ветеринарні науки
}

Scientific Messenger of Lviv National University

of Veterinary Medicine and Biotechnologies.

Series: Veterinary sciences

\title{
Morphological characteristics of respiratory and digestive organs of Roman snail (Helix pomatia L., 1758)
}

\author{
M. P. Horvat, R. S. Dankovych \\ Stepan Gzhytskyi National University of Veterinary Medicine and Biotechnologies Lviv, Ukraine
}

Article info

Received 20.01.2020

Received in revised form 20.02.2020

Accepted 21.02.2020

Stepan Gzhytskyi National University of Veterinary Medicine and Biotechnologies Lviv, Pekarska Str., 50, Lviv, 79010, Ukraine.

Tel.: +38-066-528-04-39 E-mail: marina.horvat.p@gmail.com
Horvat, M. P., \& Dankovych, R. S. (2020). Morphological characteristics of respiratory and digestive organs of Roman snail (Helix pomatia L., 1758). Scientific Messenger of Lviv National University of Veterinary Medicine and Biotechnologies. Series: Veterinary sciences, 22(97), 7-12. doi: $10.32718 /$ nvlvet 9702

The aim of this work was to study the structure of lung and hepatopancreas of Roman snail (Helix of pomatia of L., 1758). The study found that the lung occupies the lower turn of shell and presented by a saccate cavity, in the wall of that there are a kidney and heart with a pericardium, and also a rectum and ureter pass. An external surface of lungs covered by a shell and covered by an epidermis. An internal surface is covered by a flat ciliated epithelium and forms numerous folds in which pulmonary vessels and lacunae are accommodated. The branches of pulmonary vein have a thick muscular wall, that consists of circular and longitudinal muscular layers. An internal surface of lungs covered by the layer of mucus. Inhalation and exhalation are carried out due to reduction and relaxation of muscles of dorsal wall of the body that is named a "diaphragm". Gas exchange occurs through the hemolymphatic capillaries of the lung wall. Respiratory motions take place not rhythmically, but through the different intervals of time depending on a requirement in oxygen. The frequency of pneumostome closing and opening is typically one time in a minute. At subzero humidity of atmospheric air of pneumostome closed by a mantle, and also one (or a few) epiphragms. The hepatopancreas ("liver" or liver gland) is in the upper rotation of the sink and formed by two parts: right and left, from which two liver ducts enter into the stomach respectively. The liver gland consists of many acinuss, surrounded by connecting tissue, that contains small number of muscular fibres. Calcium cells have a pyramidal form and usually do not reach the lumen of the acinus. Cytoplasm of calcium cells contains inclusions: grains of phosphoricacid lime and drops of fat. The digestive cells of the hepatopencreas are more elongated, often clavicular. Cytoplasm of digestive cells is loose and vacuolated and contain inclusions of yellow-green color. Enzyme cells on histopreparations are difficult to distinguish from digestive ones. They contain transparent vacuoles with a large round inclusion of yellow-green color, which consists of a cluster of several grains of different sizes. Hepatopancreas performs the following functions: secretory (enzyme cells), absorption and intracellular digestion (digestive cells), preservation of nutrients and calcium (calcium cells), and also excretory function.

Key words: Helix pomatia, Roman snail, morphology, lung, hepatopancreas.

\section{Морфологічна характеристика органів дихання і травлення виноградного равлика (Helix pomatia L., 1758)}

\author{
М. П. Горват, Р. С. Данкович
}

Львівський національний університет ветеринарної медицини та біотехнологій імені С. 3. Гжсиџького, м. Львів, Украӥна

Метою даної роботи стало вивчення будови легені та гепатопанкреаса виноградного равлика (Неlix ротатіа L., 1758). Під час дослідження встановлено, щчо легеня займає нижній оберт раковини і представлена мішкоподібною порожниною, в стіниі якої міститься нирка і серие з перикардом, а також проходять пряма кишка та сечовід. Зовнішня поверхня легені вистелена 
епідермісом та вкрита раковиною. Внутрішня поверхня вистелена плоским війчастим епітелієм $і$ утворює численні складки, в яких розміщені легеневі судини та лакуни. Гілки легеневої вени мають товсту м'язову стінку, шзо складається з цииркулярного $і$ поздовжнього м'язового шарів. Внутрішня поверхня легені вкрита шаром слизу. Вдих $і$ видих здійснюється завдяки скороченню $i$ розслабленню м'язів дорсальної стінки тіла, які називаються “діафрагмою”. Газообмін відбувається через гемолімфатичні капіляри легеневої стінки. Дихальні рухи відбуваються не ритмічно, а через різні проміжск часу залежно від потреби в кисні. За нормальних умов пневмостом відкривається $i$ закривається приблизно один раз в хвилину. За низької вологості атмосферного повітря пневмостом закривається мантією, а також однією (або декількома) епіфрагмами. Гепатопанкреас (“печінка”, або печінкова залоза) міститься у верхніх обертах раковини і утворений двома долям: правою і лівою, від яких в шлунок впадають відповідно дві печінкові протоки. Печінкова залоза складається з багатьох ачинусів, оточених сполучною тканиною, яка містить нечисленні м'язові волокна. Стінка ацинусів вкрита високим епітелієм, що складається із клітин трьох типів: кальцієвих, травних $i$ ферментних (екскреторних). Кальцієві клітини мають пірамідальну форму $i$ зазвичай не досягають просвіту ацинуса. В циитоплазмі кальцієвих клітин містяться включення: зерна фосфорнокислого вапна і краплі жиру. Травні клітини гепатопенкреаса більш витягнуті, нерідко булавовидні. Цитоплазма травних клітин рихла та вакуолілована, містить включення жсовто-зеленого кольору. Ферментні клітини на гістопрепаратах важко відрізнити від травних. Вони містять прозорі вакуолі з великим круглим включенням жовто-зеленого кольору, яке складається зі скупчення декількох зерен різного розміру. Гепатопанкреас виконує такі функиї: секреторну (ферментні клітини), всмоктування $і$ внутрішньоклітинного травлення (травні клітини), збереження поживних речовин і Кальиію (кальц̧ієві клітини), а також екскреторну функцію.

Ключові слова: Helix ротатіа, виноградний равлик, морфологія, легеня, гепатопанкреас.

\section{Ветуп}

Helix pomatia Linnaeus, 1758 р. належить до класу черевоногих. Цей вид найповніше описаний в малакологічній літературі, оскільки $є$ модельним організмом. Особливо добре морфологію даного виду описано в монографіях Meisenheimer (1912) та Kilias (1960). Вихід даного виду на сушу став можливим завдяки змінам в будові і функції деяких основних органів. В даній статті досліджено морфофункціональну характеристику таких органів виноградного равлика, як легеня і печінка.

Мантійна або легенева порожнина (“легеня”) у молюсків під час онтогенезу утворюється за допомогою інвагінації мантійного краю і вторинно зливається з паліальною порожниною (Fretter, 1980). Легеня розглядалася як гомологічна 3 мантійною порожниною передньозябрових (Ruthensteiner, 1997). Загальна поверхня легені равлика масою 13 г становить 107,5 см² (Wilbur \& Yonge, 1966). Деякі автори вказують на те, що легенева порожнина також може служити як водосховище (Blinn, 1964). Цю особливість розглядав Solem (1978) як важливе пристосування для виживання равликів на суші.

Гепатопанкреас (“печінка”, або печінкова залоза, або травна залоза) виноградного равлика - орган, який відповідає за травлення, всмоктування та зберігання корму (Biedermann, 1911). Це великий темно-коричневий орган, що займає більшу частину всієї вісцеральної маси і виробляє численні ферменти, включаючи целюлазу, $\alpha$ - та $\beta$-глюкозидази, $\alpha$ - та $\beta$ галактозидази, фруктосахаразу та інші, такі як ліхеназа (Kruger, 1933; Vonk, 1937). Протеїнази та амінополіпептидази (Rosen, 1934) і одна або більше ліпаз (Kuntara, 1934) також були виявлені або в секреті, або в речовині самої залози. Наявні дослідження окиснення субстратів циклу Кребса та активності його ферментів у гепатопанкреасі виноградного равлика (Baldwin, 1938).

За допомогою світлового мікроскопа були проведені дослідження клітин травної залози легеневих черевоногих (Sumner, 1965). Також проводились дослідження клітин травної залози легеневих равликів 3 використанням електронного мікроскопа (Sumner, 1965; 1966).

У вітчизняній літературі наведено мало відомостей про морфологію і фізіологію органів дихання та травлення виноградного равлика. Тому метою даної роботи стало вивчення будови на макро- та гістологічному рівнях, функцій легені та гепатопанкреаса виноградного равлика (Helix pomatia L., 1758).

\section{Матеріал і методи досліджень}

Матеріалом для досліджень були особини Helix pomatia L., 1758, від яких для гістологічного дослідження відібрали гепатопанкреас i легеню. Фрагменти органів фіксували у 10 \% нейтральному формаліні. Після зневоднення у висхідному ряду спиртів матеріал заливали у парафін (Goralsky et al., 2005; Mulish \& Welsh, 2010). Гістологічні зрізи виготовляли за допомогою санного мікротома МC-2. Гістологічне дослідження препаратів та їх фотографування проводили 3 використанням мікроскопа Leica DM-2500 (Switzerland), фотокамери Leica DFC450C i програмного забезпечення Leica Application Suite Version 4.4.

\section{Результати та їх обговорення}

1. Морфо-функиіональна характеристика легені виноградного равлика (Helix pomatia L., 1758).

Органи дихання виноградного равлика представлені мантійною (легеневою) порожниною. Вона розташована в дистальній частині нутрощевого мішка, що займає нижній оберт раковини. Мантійна порожнина виконує у стебельчастооких молюсків функцію легені, тобто пристосована до дихання атмосферним киснем. Назовні легенева порожнина відкривається пневмостомом (дихальним отвором) на правому боці тіла равлика.

Макроскопічно легеня виноградного равлика представлена мішкоподібною порожниною 3 гемолімфатичними судинами, розміщеними густою сіткою на дорсальній стінці, що збільшує дихальну 
поверхню. Система судин за типом галуження нагадує гілку дерева i заповнена гемолімфою, яка містить дихальний пігмент гемоціанін, до складу якого входить Мідь. Цей білок в незв'язаному стані безбарвний, а зв'язавши кисень, набуває синього кольору. Гемолімфа переходить 3 порожнини тіла в судини, що оточують легеню (венозне коло), потім в легеневе сплетіння, де поглинається $\mathrm{O}_{2}$ і виділяється $\mathrm{CO}_{2}$. Гемолімфа повертається в серце через легеневу вену. Головна судина - легенева вена - спрямована до серця i на деякій відстань проходить дотично до нирки.

Всередині, 3 внутрішнього боку мантійної порожнини, розміщені нирка і перикард із серцем, що прилягає до нирки. На правому боці порожнини, в напрямку до зовнішнього краю мантії, проходить пряма кишка, яка закінчується порошицею справа від дихального отвору. Паралельно до прямої кишки i трохи лівіше від неї проходить короткий вторинний сечовід. Доходячи до заднього краю мантійної порожнини, він повертає наліво і з'єднується 3 первинним сечоводом. Зовнішній отвір сечоводу міститься лівіше анального. Дно легені випукле, гладке і не містить великих судин (рис. 1). Крізь нього просвічуються внутрішні органи: справа - статеві органи, зліва - зоб і слинні залози.

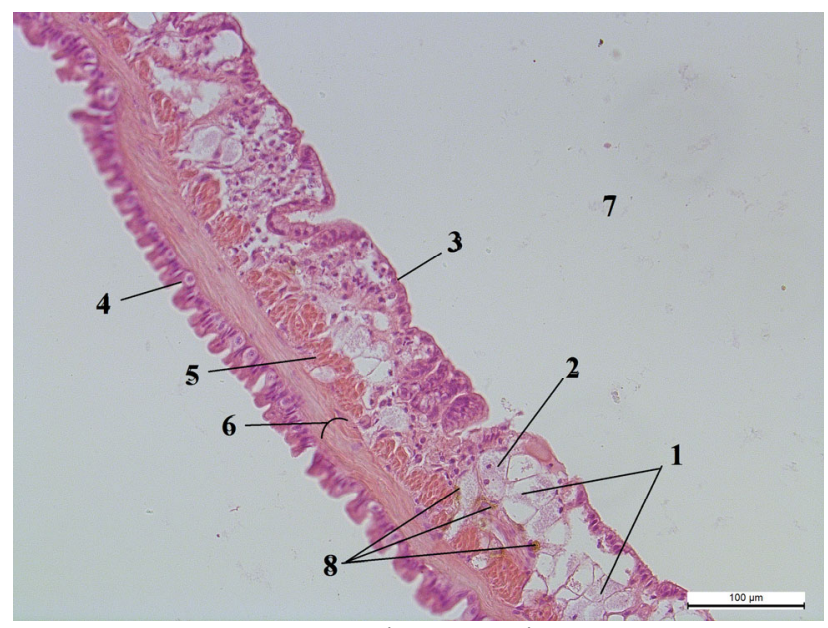

Рис. 1. Вентральна стінка мантійної порожнини

H. pomatia: 1 - лакуни, 2 - гемолімфа,

3 - респіраторний епітелій, 4 - зовнішня стінка,

5 - циркулярний м'язовий шар, 6 -повздовжній м'язовий шар, 7 - мантійна порожнина, 8 - пігментні

клітини. Гематоксилін та еозин. Збільшення $\times 200$

Зовнішня поверхня легені вкрита раковиною i вистелена епідермісом. Вся внутрішня поверхня легеневої порожнини вкрита складками і вистелена плоским війчастим епітелієм. В складках стінки легені залягають легеневі гемолімфатичні судини (рис. 2). Кровоносна система молюсків незамкненого типу. Гемолімфа циркулює в організмі не лише по судинах, а й по системі лакун і синусів - це проміжки між елементами тканин (лакуни) і між органами (синуси), які не мають власної стінки. В легеневій стінці лакуни сильно розвинуті в сполучній тканині, містяться одразу під респіраторним епітелієм та дене-де сполучаються з порожнинами судин (рис. 1).

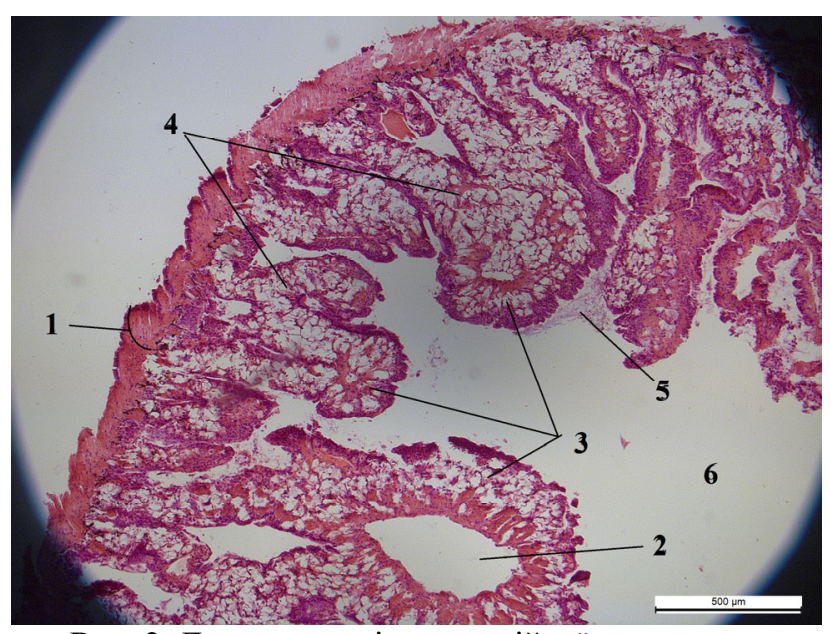

Рис. 2. Дорсальна стінка мантійної порожнини H. pomatia: 1 - зовнішня стінка, епідерміс, 2 - легенева вена, 3 - трабекули легеневого сплетення, 4 - сполучна тканина, 5 -шар слизу, 6 - мантійна порожнина. Гематоксилін та еозин. Збільшення $\times 50$

Гілки легеневої вени мають товсту м'язову стінку, що складається 3 циркулярного i поздовжнього м'язового шарів і заповнені гемолімфою (рис. 3). Внутрішня поверхня легені вкрита шаром слизу (рис. 1, 4). В сполучній тканині стінки легеневої порожнини залягає пласт циркулярних м'язових волокон. Навколо гемолімфатичних судин, що проходять в легеневій стінці, локалізовані повздовжні м'язові пучки. В сполучній тканині легені трапляються пігментні клітини, інколи в великій кількості (рис. 1).

Равлики здійснюють вдих і видих через невеликий легеневий отвір завдяки скороченню і розслабленню м'язів дорсальної стінки тіла. Ці м'язи називають “діафрагмою”. Порожнина легені заповнюється повітрям, коли пневмостом відкривається і “діафрагма" скорочується для розширення легені фаза вдиху. Через деякий час пневмостом закривається і діафрагма розслабляється, внаслідок чого утворюється невеликий надлишок тиску всередині легеневої порожнини - фаза видиху. Газообмін відбувається через гемолімфатичні капіляри легеневої стінки та цикл починається знову.

Дихальні рухи відбуваються не ритмічно, а через різні проміжки часу залежно від потреби виноградного равлика в кисні. Відкривання пневмостома і видихання повітря відбувається тоді, коли в легеневій порожнині нагромаджується значна кількість вуглекислоти, що і викликає рефлекторне відкриття пневмостома. За нормальних умов у виноградного равлика пневмостом відкривається i закривається приблизно один раз на хвилину. За умов концентрації великою кількості вуглекислоти в довкіллі дихальні рухи стають частішими.

За низької вологості атмосферного повітря 
пневмостом закривається мантією, а також однією (або декількома) епіфрагмами для обмеження дифузійних втрат водяної пари та запобігання висушуванню. Епіфрагма - мінералізований слизовий шар, який перешкоджає газообміну і затримує вологу у мантійній порожнині. За підвищеної вологості повітря епіфрагма виявляє гігроскопічні властивості й не забезпечує надійного утримання вологи в легеневій порожнині.

У зв'язку з наземним способом життя змінилася частково i будова шкірного покриву, особливо у великих равликів, до яких належить виноградний равлик. У них шкіра набула характерного зморшкуватого вигляду. Ці зморшкуваті потовщення шкіри повільно пульсують. Ця пульсація має значення в процесі шкірного дихання, яке у наземних равликів доповнює легеневе дихання (Ivanov et al., 1985).

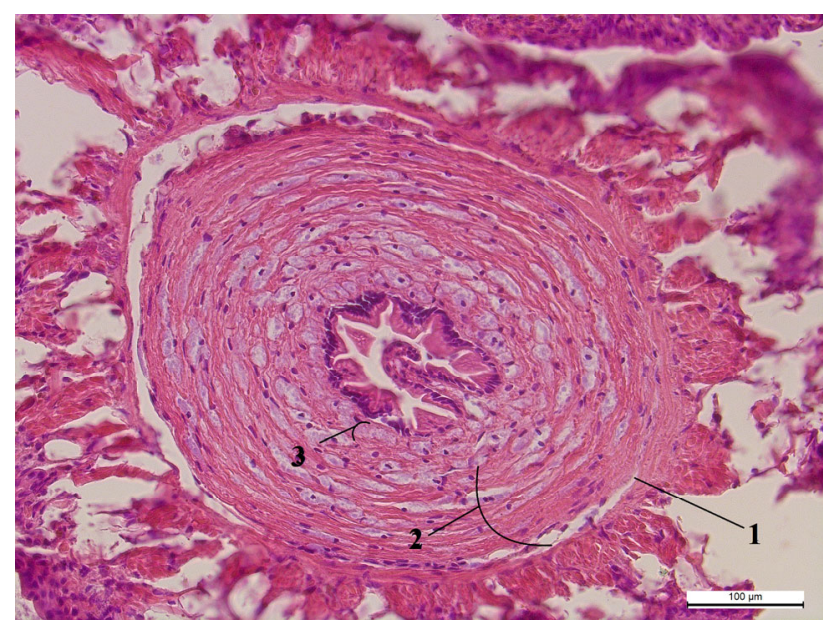

Рис. 3. Дорсальна стінка мантійної порожнини H. Pomatia: 1 - легенева вена, 2 - циркулярний м'язовий шар, 3 - повздовжній м'язовий шар.

Гематоксилін та еозин. Збільшення $\times 200$

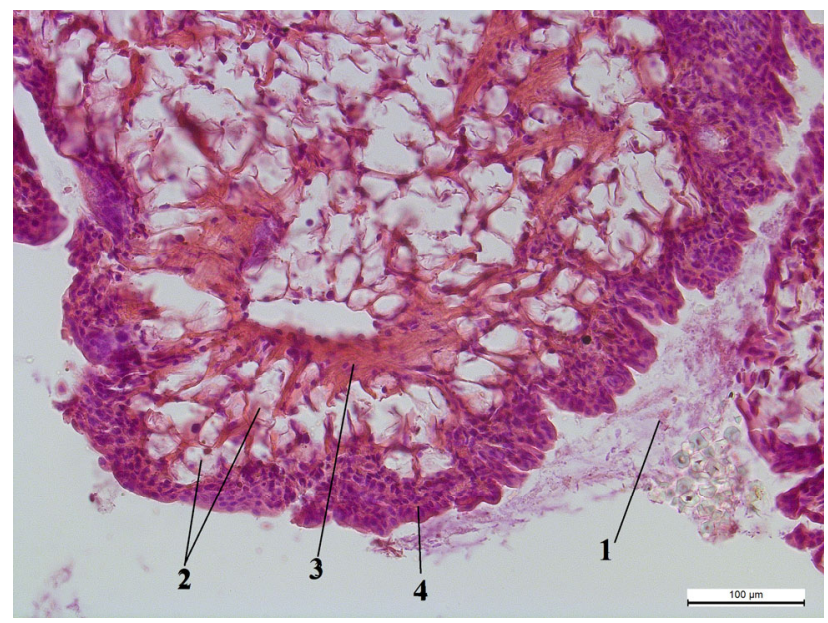

Рис. 4. Дорсальна стінка мантійної порожнини

H. pomatia: 1 - шар слизу, 2 - лакуни, 3 - м'язові елементи, 4 - респіраторний епітелій. Гематоксилін та еозин. Збільшення $\times 200$
2. Морфо-функціональна характеристика гепатопанкреаса виноградного равлика (Helix pomatia L., 1758).

Травна система виноградного равлика представлена ротовою порожниною, глоткою, слинними залозами і залозами Налепа, стравоходом, який утворює зоб, шлунком, гепатопанкреасом (печінкою, або печінковою залозою, або травною залозою), тонкою та прямою кишками і закінчується анальним отвором.

Гепатопанкреас міститься у верхніх обертах раковини і складається 3 двох долей: правої і лівої. Права доля займає верхні оберти завитка нутрощевого мішка, повторюючи їх за формою (рис. 5). До внутрішнього боку цієї долі тісно прилягає гермафродитна залоза. Ліва доля печінки міститься в середніх обертах завитка спереду від шлунка і поділяється на дві лопасті, одна 3 яких витягнута, а інша - більш широка i округла, розміщена під першою лопастю.

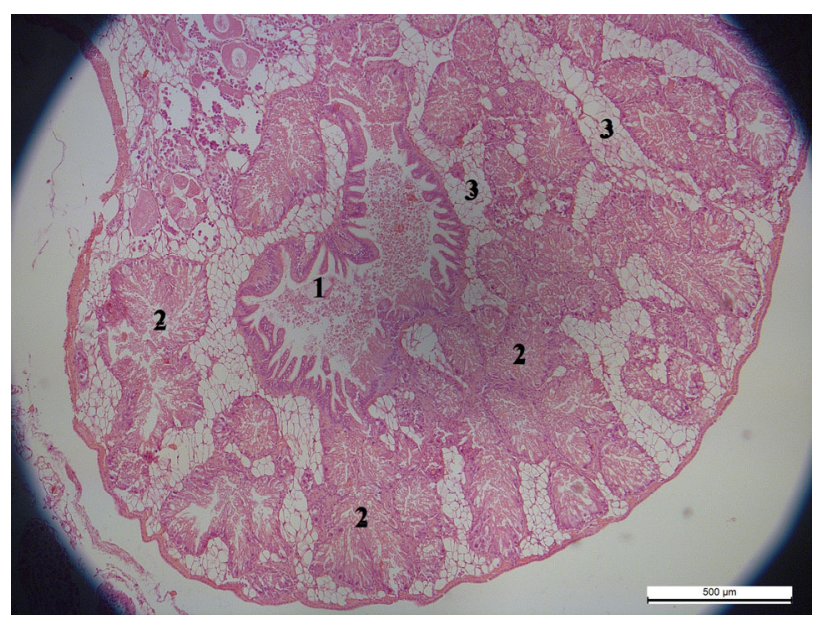

Рис. 5. Права доля печінки H. pomatia:

1 - печінкова поротока, 2 - ацинуси, 3 - сполучна тканина. Гематоксилін та еозин. Збільшення $\times 50$

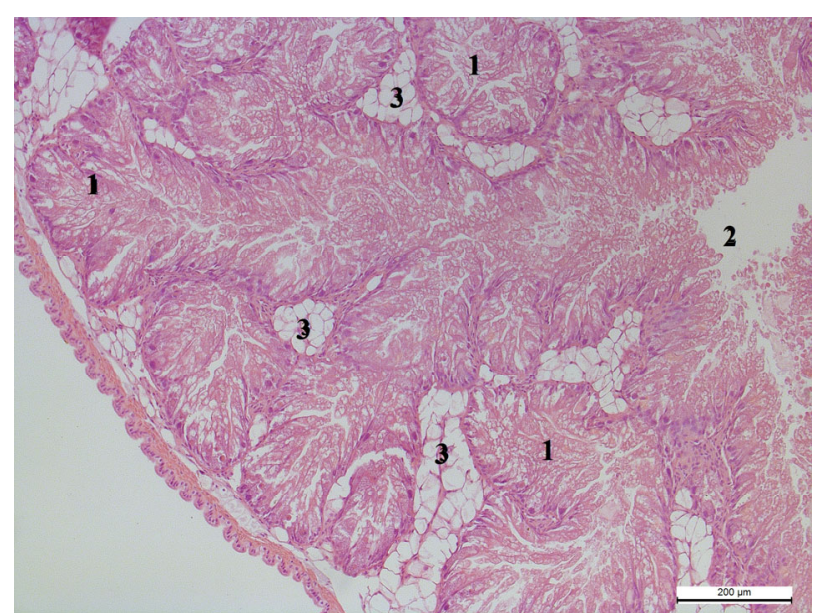

Рис. 6. Печінка H. pomatia: 1 - ацинуси, 2 - печінкова протока, 3 - сполучна тканина. Гематоксилін та еозин. Збільшення $\times 100$ 
Між долями гепатопанкреаса проходять петлі тонкої кишки, які з'єднуються із залозою за допомогою сполучної тканини.

На внутрішній поверхні печінкових долей розташовані протоки (рис. 5, 6), які відкриваються в шлунок двома отворами. Протока правої долі впадає в шлунок на його верхівці, протока лівої долі безпосередньо над входом в тонку кишку.

Гепатопанкреас належить до залоз, що складаються з багатьох ацинусів (рис. 4-8), оточених сполучною тканиною, що містить нечисленні м'язові волокна. Стінка ацинусів вкрита високим епітелієм, який складається із клітин трьох типів: кальцієвих, травних і ферментних (екскреторних).

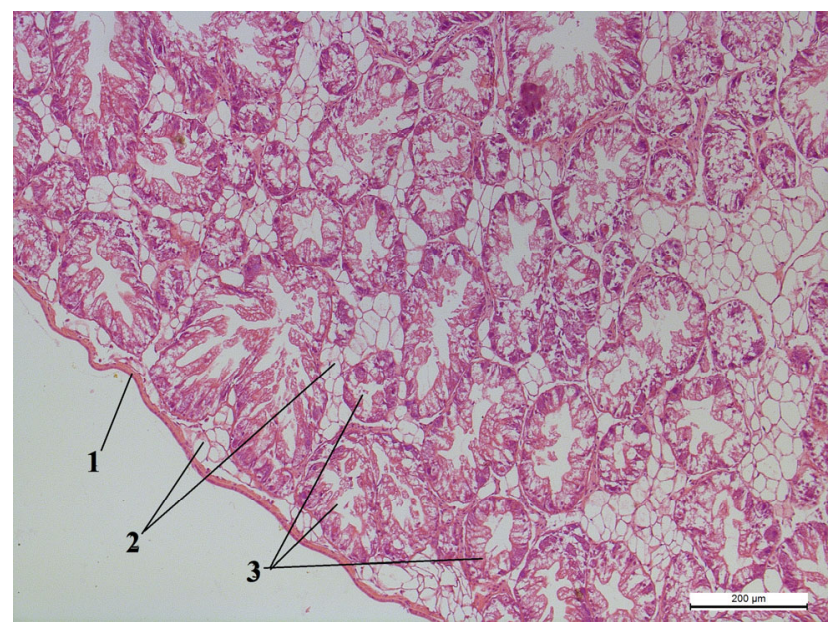

Рис. 7. Печінка $H$. pomatia: 1 - оболонка, 2 - сполучна тканина, 3 - ацинуси. Гематоксилін та еозин. Збільшення $\times 100$

Гепатопанкреас виконує декілька функцій. Як травна залоза він виділяє ферменти, які утворюються у ферментних клітинах. Секрет цих клітин надходить в зоб, де діє на харчову грудку: забезпечує емульгування жирів i переведення клітковини у розчинний стан. Харчова маса 3 зобу надходить в шлунок і звідси по печінкових протоках в порожнину печінки. Розчинені поживні речовини всмоктуються, а білкові частинки фагоцитуються травними клітинами, де піддаються внутрішньоклітинному травленню. Гепатопанкреас також виконує функцію органу, в якому відкладаються запасні поживні речовини: глікоген і фосфорнокисле вапно - в клітинах печінки, а жир, крім цього, - також в сполучній тканині біля залози. Екскреторна функція полягає у виведенні неперетравлених частинок назад у шлунок, а потім - в тонку кишку у вигляді печінкових екскрементів.

Кальцієві клітини мають пірамідальну форму i зазвичай не досягають просвіту ацинуса. В кожній кальцієвій клітині ядро розміщене базально, неправильної форми, велике і добре забарвлюється гематоксиліном. В цитоплазмі містяться включення: зерна фосфорнокислого вапна, які інтенсивно забарвлюються гематоксиліном, і краплі жиру.

Травні клітини гепатопенкреаса більш витягнуті, нерідко булавовидні. Ядра їх менші, ніж у кальцієвих клітин, та розміщені базально. Цитоплазма рихла та вакуолілована. Містять включення жовтого-зеленого кольору (рис. 8), які виводяться клітинами в порожнину печінки. Цьому типу клітин приписується резорбція жиру i білків, а також ферментативна i секреторна функція (Sumner, 1965; Ivanov et al., 1985).

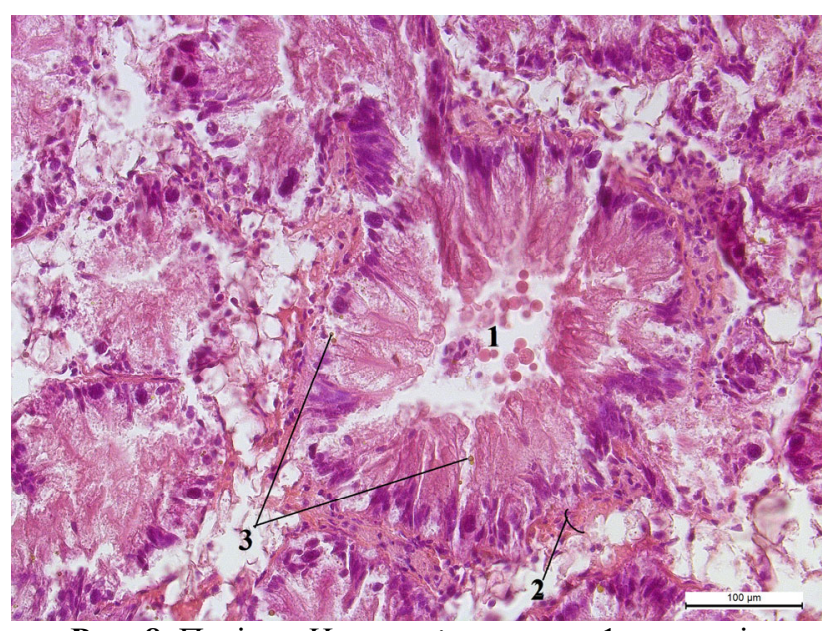

Рис. 8. Печінка $H$. pomatia, ацинус: 1 - просвіт ацинуса, 2 - стінка ацинуса, 3 - включення в травних клітинах. Гематоксилін та еозин. Збільшення $\times 200$

Ферментні клітини на гістопрепаратах важко відрізнити від травних. Вони містять прозорі вакуолі 3 великим круглим включенням жовто-зеленого кольору, яке складається зі скупчення декількох зерен різного розміру. Для ідентифікації цих включень ферментних клітин застосовують гістохімічні методики 3 фарбуванням осмієвою кислотою. Із цитоплазми ферментних клітин гранули ферментів потрапляють в порожнину печінки, а потім в шлунок та зоб.

\section{Висновки}

Легеня Helix pomatia L., 1758 являє собою мішкоподібну структуру, вкриту шаром слизу, в стінках якої густо розміщені гемолімфатичні судини, через які здійснюється газообмін. Стінка легені утворює численні складки, у яких проходять легеневі судини і міститься складна система лакун. Вдих та видих відбувається через пневмостом завдяки скороченню i розслабленню циркулярних м'язів стінки легеневої порожнини. Дихальні рухи здійснюються не ритмічно, а залежно від вмісту вуглекислого газу в закритій порожнині. Для обмеження втрат вологи легеневий отвір може закриватися епіфрагмою. Додаткову роль у газообміні виконує шкірне дихання.

Гепатопанкреас займає верхні оберти нутрощевого мішка, повторюючи їхню форму, і складається 3 двох долей, від яких в шлунок впадають відповідно дві печінкові протоки. Печінкова залоза складається 3 багатьох ацинусів, стінка яких вкрита трьома типами клітин: кальцієвими, травними i ферментними. Завдяки своїй будові гепатопанкреас виконує багато 
функцій: секреторну (ферментні клітини), всмоктування i внутрішньоклітинного травлення (травні клітини), збереження поживних речовин i Кальцію (кальцієві клітини), а також екскреторну функцію.

Перспективи подальших досліджень: провести гістохімічне та ультраструктурне дослідження внутрішніх органів виноградного равлика, а також вивчати патологоанатомічні зміни у молюсків за розвитку захворювань різної етіології.

\section{References}

Baldwin, E. (1938). On the respiratory metabolism of Helix pomatia. Biochemical Journal, 32(7), 12251237. doi: 10.1042/bj0321225.

Biedermann, W. (1911). Winterstein's Handbuch der vergleichenden Physiologie. Band, 2(1), 1049-1361.

Blinn, W. C. (1964). Water in the mantle cavity of land snails. Physiological Zoology, 37(3), 329-337. doi: 10.1086/physzool.37.3.30152403.

Fretter, V. (1980). The evolution of some higher taxa in gastropods. In: Symposium on the biology and evolution of Mollusca. Journal of the Malacological Society of Australia, 4(4), 226-227. doi: 10.1080/00852988.1980.10673931.

Goralsky, L. P., Homich, V. T. \& Kononsky, O. I. (2005). Osnovi gistologichnoi tekhniku i morfofynctsionalni doslidzhenna y normi ta pru patologii [Basics of gistological of tehnik and morfofunctional metods researches in norma and patology] Zhitomir, "Polissya" (in Ukrainian).

Ivanov, A. V., Poljanskij, Ju. I., \& Strelkov, A. A. (1985). Bol'shoj praktikum po zoologii bespozvonochnyh. Chast' 3. Tipy: sipunkulidy, molljuski, shhupal'cevye, iglokozhie. Vyshaja shkola, Moskva (in Russian).

Kilias, R. (1960). Weinbergschnecken. Ein Überblick über ihre Biologie und wirtschaftliche Bedeutung. 94 pp. Veb Deutscher Verlag der Wissenschaften, Berlin.

Krüger, P. (1933). Vergleichender Fermentstoffwechsel der niederen Tiere. Ergebnisse der Physiologie und Experimentellen Pharmakologie, 35(1), 538-572. doi: 10.1007/bf02331364.

Kuntara, W. (1934). Beitrag zur Kenntnis der Lipase aus dem Darmsaft der Weinbergschnecke (Helix pomatia).
I. Mitteilung über Helixenzyme. Hoppe-Seyler's Zeitschrift für physiologische Chemie, 225(4), 169188. doi: 10.1515/bchm2.1934.225.4.169.

Lőw, P., Molnár, K., \& Kriska, G. (2016). Atlas of Animal Anatomy and Histology. Springer Nature, Germany. doi: 10.1007/978-3-319-25172-1.

Meisenheimer, J. (1912). Die Weinbergschnecken Helix pomatia L. Monographien einheimischer Tiere. Band 4. Verlag von Dr. Werner Klinkhardt, Leipzig. doi: $10.5962 /$ bhl.title.10627.

Mulish, M., \& Welsh, U. (2010). Romeis. Mikroscopiche technic. Heidelberg, 127-154.

Rosén, B. (1934). Die Proteinase und die Aminopolypeptidase der Mitteldarmdrüse von Helix pomatia. Z. vergl. Physiol., 21, 176-187. doi: $10.1007 / \mathrm{bf00713484}$.

Ruthensteiner, B. (1997). Homology of the pallial and pulmonary cavity of Gastropods. Journal of Molluscan Studies, 63(3), 353-367. doi: 10.1093/mollus/63.3.353.

Solem, A. (1978). Classification of the land mollusca. FRETTER, V. \& PEAKE, J., 49-98.

Sumner, A. T. (1965). The cytology and histochemistry of the digestive gland cells of Helix. Journal of Cell Science, 106(2), 173-192. https://www.ncbi.nlm.nih. gov/pubmed/4158164.

Sumner, A. T. (1966). The fine structure of digestivegland cells of Helix, Succinea and Testacella. Journal of the Royal Microscopical Society, 85(2), 181-192. doi: 10.1111/j.1365-2818.1966.tb02179.x.

Tillier, S. (1989). Comparative morphology, phylogeny and classification of land snails and slugs (Gastropoda: Pulmonata: Stylommatophora). Malacologia, 30, 1-303.

Vonk, H. J. (1937). The specificity and collaboration of digestive enzymes in metazoa. Biological Reviews, 12(2), 245-284. doi: 10.1111/j.1469185x.1937.tb01231.x.

Wilbur, K. M., \& Yonge, C. M. (1966). Physiology of Mollusca. Volume 2. New York and London: Academic Press doi: 10.1002/iroh.19730580628.

Zenkevich, L. A. (1968). Zhizn' zhivotnyh. V 6 tomah. Tom 2. Bespozvonochnye. M.: Prosveshhenie, Moskva (in Russian). 